\title{
EMPIRICAL STUDY OF THE CHARACTERISTICS OF AFZELIA AFRICANA SEED UNDER COMPRESSIVE LOADING
}

\author{
C. 0. Nwajinka ${ }^{1}{ }^{*}$, C. U. Onuegbu ${ }^{2}$ and D. O. Amaefule ${ }^{3}$

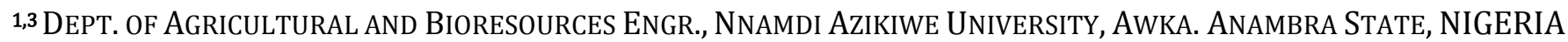 \\ 2, Department of Agricultural EngineEring, Federal Polytechnic, OKO. ANAMBra State, NiGERIA \\ E-mail addresses:1 oc.nwajinka@unizik.edu.ng, 2 ocaesars47@gmail.com, 3 doamaefule@gmail.com
}

\begin{abstract}
Afzelia Africana seeds were subjected to quasi-static parallel plate compression test, using Monsanto Tensometer. The loading orientations were horizontal, vertical and edge-to-edge loading positions at four different moisture content levels of $10.6 \%, 12.8 \%, 15.2 \%$ and $18.4 \%$ wet basis (wb). Slight variations were observed in the means of the physical characteristics at varying moisture content in the range of $10.6 \%$ to $18.4 \%$. Loading position was shown to have significant effect on all the mechanical properties studied. The rupture force increased with increase in moisture content in horizontal and vertical loading but did not show consistent trend in variation when loaded on the edges. This value was $155.68 \mathrm{~N}$ for vertical loading, $139.27 \mathrm{~N}$ for horizontal loading and $81.0 \mathrm{~N}$ for edge-to-edge loading. Hardness ranged from 6.97 to $6.92 \mathrm{~N} / \mathrm{mm}$ for horizontal loading, 6.92 to $6.67 \mathrm{~N} / \mathrm{mm}$ for edge-loading and 6.99 to $6.93 \mathrm{~N} / \mathrm{mm}$ for vertical loading respectively in the moisture content range of 10.6 to $18.4 \%$ for all cases. Rupture energy varied from 104 to $416.33 \mathrm{~N}$-mm on horizontal loading, 59.96to 241.82 on edge-loading and 190.125 to $419.171 \mathrm{Nmm}$ on vertical loading respectively for the same range of moisture content. Toughness varied from 43.758 to $8.865 \mathrm{~N}-\mathrm{m} / \mathrm{mm}, 23.563$ to 5.370 and 44.667 to $16.349 \mathrm{~N}-\mathrm{m} / \mathrm{mm}$ for horizontal loading, edge-edge orientation, and vertical loading respectively, for moisture content range of 10.6 to 18.4\%.Modulusof Elasticity dropped from 35.657 to $28.133 \mathrm{~N} / \mathrm{mm}^{2}$ for horizontal loading, from 51.443 to 14.59 for edge-to-edge loading and 38.087 to $41.04 \mathrm{~N} / \mathrm{mm}^{2}$ for vertical loading in the range of moisture content of 10.6 to $18.4 \%$ respectively. The data generated in this study can be applied when estimating the energy and force needed for shelling the seeds and in making useful suggestions on the loading condition that will demand the least energy for the operation and shelling. The physical properties are also useful in process design and analysis.
\end{abstract}

Keywords: Afzelia Africana, Mechanical Properties, Physical properties, quasi compression

\section{INTRODUCTION}

1.1 The Afzelia Africana seed.

Afzelia Africana is a hard seed with dark brown to black coloration arranged in a pod of $12-17 \mathrm{~cm} \times 5-8 \mathrm{~cm} \times 3-5$ $\mathrm{cm}$ dimensions as shown in figures 1aand1b:and slightly rounded with a distinct beak-like cap at one end. Each pod contains several black seeds beautifully arranged in rows when cut along the line of symmetry [1], [2].

The high value of its oil, its rapid growth rate and the high nutritional content of the seeds make Afzelia Africana an economically useful crop [3]. The average moisture content of the seeds from various locations was $5.56 \%$, crude protein $26.44 \%$ and crude oil content $33.32 \%$ [4]. The oil extracted from this seed can be used for domestic and industrial purposes. Physical and mechanical properties of the seeds are required for development of their postharvest handling and processing machinery and equipment.

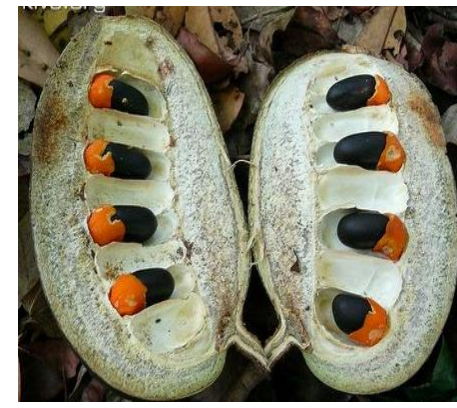

(a)

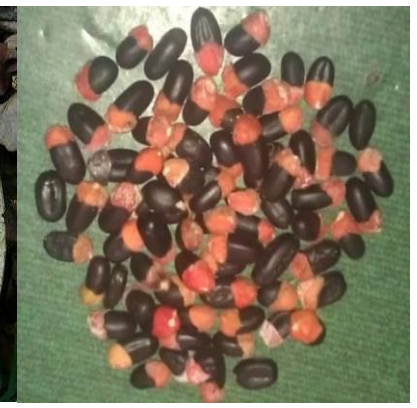

(b)
Figure 1: (a) Split Pod of Afzelia Africana showing arrangement of Seeds, (b) Afzelia Africana Seeds The aim of this study is therefore to experimentally determine the physical and mechanical properties of 
Afzelia Africana seeds, such as hardness, toughness, energy at rupture, and modulus of elasticity by subjecting them to quasi-static compression loading.

\section{MATERIALS AND METHODS}

\subsection{Sample Preparation}

Samples of mature Afzelia Africana (akpalata in Igbo language) seeds were locally procured from Awka, in Anambra State, Nigeria. The seeds were subsequently identified in Botany department of Nnamdi Azikiwe University, Awka. They were thereafter, cleaned and used for the requisite experiments. A set of samples of one hundred (100) seeds each were soaked in water for $12 \mathrm{~h}, 18 \mathrm{~h}, 24 \mathrm{~h}$ and $36 \mathrm{~h}$, respectively, and the moisture content level was determined.

\subsection{Determination of Physical Properties}

The physical properties of Afzelia Africana were determined at different moisture contents which were arrived at by reconstitution as described in section 2.1.

\subsubsection{Moisture Level Determination}

The moisture content of the seeds was determined by oven-drying method [5], [6]. This involved drying the seeds in an oven (OKH-HX-1A, Japan) at $103^{\circ} \mathrm{C} \pm 1$ for 72 $\mathrm{h}$ until there was no subsequent change in its mass. The samples of Afzelia Africana seeds were weighed with a digital weighing balance (Mettler Tolado, Japan) with accuracy of $\pm 0.001 \mathrm{~g}$. To avoid buoyancy effect during weighing and to ensure there was no re-absorption of moisture, the seed samples were left to cool in Desiccators before weighing. The difference in weight before and after oven-drying gave the moisture content. The following moisture content levels were obtained: $10.6 \%, 12.8 \%, 15.2 \%$ and $18.4 \%$ wet bases (wb) for the samples soaked for $12 \mathrm{~h}, 18 \mathrm{~h}, 24 \mathrm{~h}$ and $36 \mathrm{~h}$, respectively. Three batches of the seeds were prepared as replicates for the experiments.

\subsubsection{Determination of Shape and Size of the Seed}

The mass (m) of Afzelia Africana was measured using an electronic weighing balance (Mettler Talodo) with accuracy of \pm 0.001 g. The Axial dimensions namely; length (L), width (W) and thickness (T)of the seeds as shown in figure2 were measured with a Venier caliper (Mitutoyo, Japan) having accuracy of $\pm 0.01 \mathrm{~mm}$.The arithmetic mean diameter, $\mathrm{D}_{\mathrm{a}}$ and geometric mean diameter, $\mathrm{D}_{\mathrm{g}}$ of the seeds were calculated using equations(1) and (2)presented in Mohsenin [7].

$$
\begin{gathered}
D_{a}=\frac{L_{1}+L_{2}+L_{3}}{3} \\
D_{g}=\sqrt[3]{L_{1} L_{2} L_{3}}
\end{gathered}
$$

In (1) and (2), $\mathrm{L}_{1}, \mathrm{~L}_{2}$ and $\mathrm{L}_{3}$ are major diameter, intermediate diameter and minor diameter respectively.

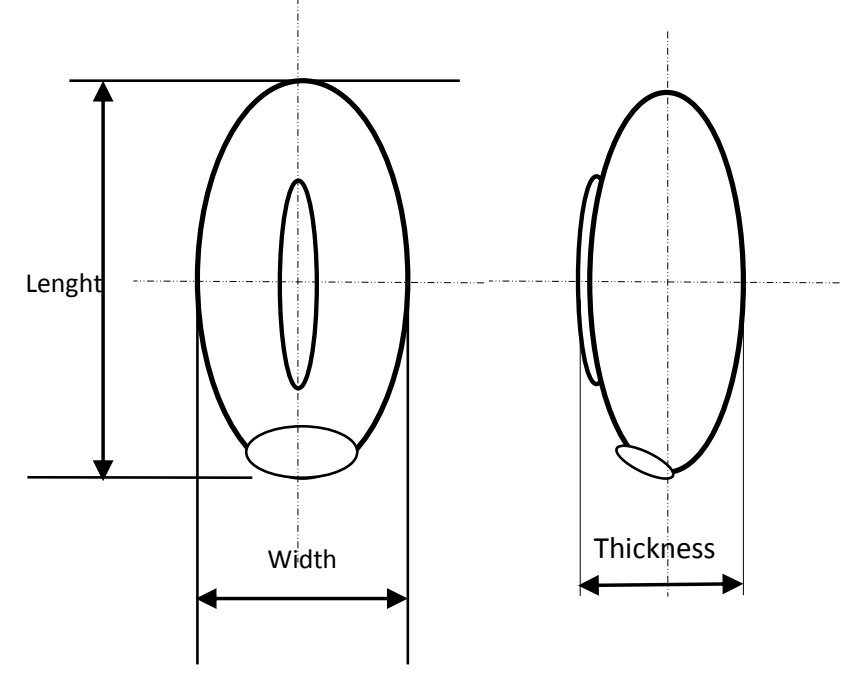

Figure2: The principal dimensions of Afzelia Africana seed

\subsubsection{Equivalent surface area Determination}

The surface area of Afzelia Africana was found by analogy with a sphere of same geometric mean diameter [8]. The equivalent surface area of the seed is evaluated using Equation 3[9]:

$$
s=\frac{\pi\left(D_{e}\right)^{2}}{4}
$$

Where, $D_{e}$ can be calculated using equation 4 .

$$
D_{e}=\left[\left(\frac{W_{t}}{\rho_{t}}\right)\left(\frac{6}{\pi}\right)\right]^{\frac{1}{3}}
$$

Where $D_{e}$ is the equivalent diameter in $(\mathrm{mm}), \mathrm{W}_{\mathrm{t}}$ is weight of seed in $\mathrm{Kg}$ and is particle density of seed in $\mathrm{Kg} / \mathrm{m}^{2}$.

\subsubsection{Sphericity Determination:}

The sphericity of the seeds was determined from the longitudinal, transverse and minor axes of the seeds. The linear dimensions obtained were used to evaluate the sphericity of the A. Africana seed using Equation (5) [7].

$$
S_{p}=\frac{\sqrt[3]{L_{1} L_{2} L_{3}}}{L_{1}}=\frac{D_{g}}{L_{1}}
$$

Where $S_{p}$ is the sphericity and $D_{g}$ is the geometric mean diameter.

\subsection{Determination of Some Mechanical Properties}

From the stress-strain data the rheological properties of Afzelia Africana seed in uniaxial compression were determined at three principal orientations corresponding to the major, intermediate and minor axes as follows: vertical, edge-to-edge and horizontal respectively. The experiments were carried out at different moisture contents which are assumed to be the moisture at various points of maturity. 
A total of 100 Afzelia Africana seeds were used for the quasi-static parallel plate compression test, using Monsanto Tensiometer shown in Figure3. The forcedeformation data in vertical edge-wise and horizontal, orientations at four different moisture content levels of $10.6 \%, 12.8 \%, 15.2 \%$ and $18.4 \%(\mathrm{wb})$ were generated. Force was applied by turning the load arm of the testing machine at $2.5 \mathrm{~mm} / \mathrm{min}$ and the seed loaded to a breaking (rupture) point. Three replications of each experimental sample conditions were made. The temperature of the laboratory was consistent at $30 \pm 2$ ${ }^{0} \mathrm{C}$.The experimental data were used to compute the modulus of elasticity, toughness, rupture force, hardness and energy required to rupture the materials.

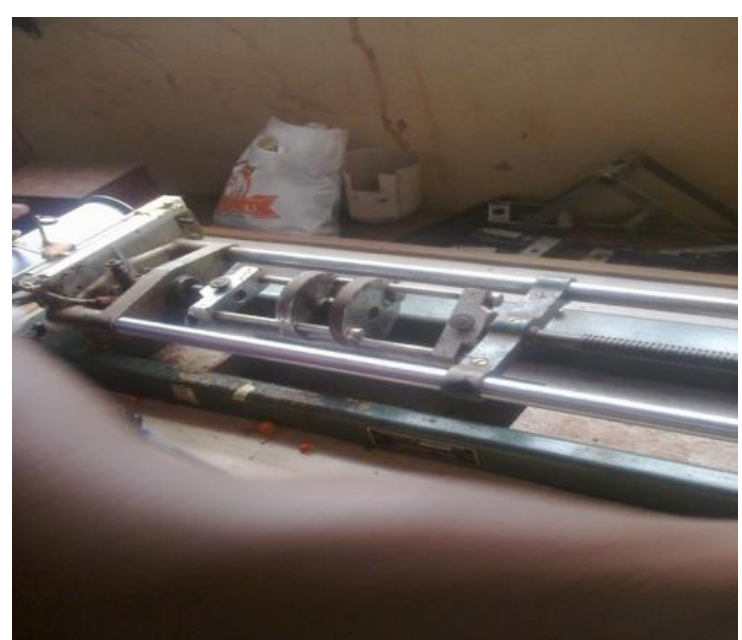

Figure 3: Monsanto tensiometer for compression tests

\subsubsection{Rupture Energy}

Rupture Energy, $E_{R}(\mathrm{~N}-\mathrm{mm})$ is the energy needed to rupture the sample, which was the product of Rupture force and deformation at rupture, presented in equation (6) [10].

$$
E_{R}=F_{R} \cdot D_{R}
$$

Where; $F_{R}=$ the minimum force required to break the sample $(\mathrm{N})$ and $\mathrm{D}_{\mathrm{R}}=$ deformation at rupture $(\mathrm{mm})$

\subsubsection{Toughness}

This is the amount of energy required per unit volume of the material to rupture. It was determined graphically by measuring the area under the force-deformation curve just before rupture. In this study, equation (7) was alternatively used [10].

$$
\text { Toughness }=\frac{\text { Rupture Energy }}{\text { Volume of material }}
$$

\subsubsection{Hardness}

Hardness, $\mathrm{H}(\mathrm{N} / \mathrm{mm})$, is the ratio of maximum axial load (N)to deformation (mm) at rupture point. This was obtained using equation8as below [11]:

$$
H=\frac{F_{\text {max }}}{\delta}
$$

Where, $F_{\max }=$ maximum axial load $(\mathrm{N})$ and $\delta=$ deformation (mm)

\subsubsection{The Modulus of Elasticity (E)}

For most agricultural materials subjected to compression, the modulus of elasticity is usually calculated from an empirical formula derived from stress-strain ratio. The modulus of elasticity of the seeds in uniaxial compression can be obtained by equation (9) [12 - 14].

$$
E=\frac{(F / A)}{(\Delta L / L)}=\frac{\sigma}{\varepsilon}
$$

Where $\mathrm{E}=$ modulus of elasticity in $\mathrm{MPa}, \mathrm{F}=$ force in $\mathrm{N}, \sigma$ $=$ Stress in the material, $\Delta L=$ total deformation in $\mathrm{mm}$, $\mathrm{L}=$ Original length of the material, $\mathrm{A}=$ Surface area of the material under compression, $\varepsilon=$ Strain caused by the stress on the material.

\section{RESULTS AND DISCUSION}

\subsection{Dimensional Characteristics}

Statistical analysis showed that the unit mass of Afzelia Africana seed was from 3.0 to $3.9 \mathrm{~g}$. The effects of moisture content on the mean Major Diameter (MD), Intermediate Diameter (ID), Minor Diameter (MnD), Arithmetic Mean Diameter (Da) and Geometric Mean Diameter (Dg) of Afzelia Africana seed was determined and presented in tables1 and 2. The Duncan's new multiple range tests was used to group the seed dimensions according to their mean sizes as shown in table 1. There is no significant variation of these characteristics with moisture content in the moisture range of $10.6 \%$ wb to $18.4 \%$ wb tested.

Table 1: Physical dimensions of Afzelia Africana seed

\begin{tabular}{cccccc}
\hline $\begin{array}{c}\text { Moisture content } \\
\text { level (\%) w.b }\end{array}$ & $\begin{array}{c}\text { Major Diameter, } \\
\mathrm{mm}\end{array}$ & $\begin{array}{c}\text { Intermediate } \\
\text { Diameter, } \mathrm{mm}\end{array}$ & $\begin{array}{c}\text { Minor Diameter, } \\
\mathrm{mm}\end{array}$ & $\mathrm{Da}(\mathrm{mm})$ & $\mathrm{Dg}(\mathrm{mm})$ \\
\hline 10.6 & $23.412 \pm 1.77^{\mathrm{a}}$ & $11.658 \pm 1.29^{\mathrm{a}}$ & $9.298 \pm 1.40^{\mathrm{a}}$ & $14.839 \pm 1.11^{\mathrm{a}}$ & $13.563 \pm 1.11^{\mathrm{a}}$ \\
12.8 & $23.432 \pm 1.79^{\mathrm{a}}$ & $11.666 \pm 1.28^{\mathrm{a}}$ & $9.305 \pm 1.40^{\mathrm{a}}$ & $14.856 \pm 1.10^{\mathrm{a}}$ & $13.631 \pm 1.09^{\mathrm{a}}$ \\
15.2 & $23.487 \pm 1.79^{\mathrm{a}}$ & $11.742 \pm 1.26^{\mathrm{a}}$ & $9.304 \pm 1.40^{\mathrm{a}}$ & $14.880 \pm 1.11^{\mathrm{a}}$ & $13.668 \pm 1.06^{\mathrm{a}}$ \\
18.4 & $23.478 \pm 1.84^{\mathrm{a}}$ & $11.844 \pm 1.04^{\mathrm{a}}$ & $9.339 \pm 1.39^{\mathrm{a}}$ & $14.888 \pm 1.11^{\mathrm{a}}$ & $13.6799 \pm 1.06^{\mathrm{a}}$ \\
\hline
\end{tabular}

Note: Means and standard deviation $( \pm)$ in columns with the same superscript are not significantly different at $p \leq 0.05$ 
Table 2: Sphericity, projected area, unit volume and aspect ratio of Afzelia Africana seed at different moisture content

\begin{tabular}{ccccc}
\hline Moisture content level (\%) w.b & Sphericity & Projected area $\left(\mathrm{mm}^{2}\right)$ & Unit volume $\left(\mathrm{cm}^{3}\right)$ & Aspect Ratio $(\%)$ \\
\hline $10.6 \%$ & 0.572 & 219.451 & 10.803 & 50.396 \\
$12.8 \%$ & 0.593 & 219.437 & 10.815 & 50.408 \\
$15.2 \%$ & 0.590 & 219.445 & 10.827 & 50.689 \\
$18.4 \%$ & 0.602 & 219.460 & 10.851 & 50.437 \\
\hline
\end{tabular}

Table 3: Means of true/bulk densities, porosity and surface area of Afzelia Africana seeds at different moisture content

\begin{tabular}{ccccc}
\hline Moisture content level (\%)w.b & True density $\left(\mathrm{g} / \mathrm{cm}^{3}\right)$ & Bulk density $\left(\mathrm{g} / \mathrm{cm}^{3}\right)$ & Porosity $(\%)$ & Surface $\left.\operatorname{area}_{(\mathrm{mm}}^{2}\right)$ \\
\hline 10.6 & 1.126 & 0.338 & 46.001 & 585.400 \\
12.8 & 0.722 & 0.340 & 46.886 & 585.417 \\
15.2 & 0.728 & 0.351 & 42.803 & 585.471 \\
18.4 & 0.756 & 0.376 & 40.653 & 585.502 \\
\hline
\end{tabular}

The effect of moisture content on true density, bulk density, porosity and surface area is presented in Table 3. The results show that there are slight changes in bulk density, porosity and surface area with change in moisture content in the range of $10.6 \% \mathrm{wb}$ to $18.4 \% \mathrm{wb}$. These variations were, however, not statistically significant probably because of the thick seed coat. True density did not show a consistent variation with change in moisture content.

\subsection{Mechanical Properties}

The mechanical properties study was conducted using the data obtained from the compressive loading of the Afzelia Africana seeds in a monsan to tensiometer.

\subsubsection{Rupture Force}

The plot of mean rupture force of the seeds against moisture content for different loading positions are presented in figure 4 . This parameter varies both with moisture content and loading position. It can be deduced from the graph that on the horizontal and vertical loading positions, the seeds' rupture force was more affected by moisture content than when on edge-to-edge position. This force is highest for vertical loading with $155.68 \mathrm{~N}$, followed by horizontal loading with $139 \mathrm{~N}$ and least for edge-wise loading with $81 \mathrm{~N}$. It can therefore be deducted from the results that in shelling operation, the seed loaded on its edges will reduce the energy requirement.

The empirical relationship between rupture force and moisture content are given in equations 10 to 12 . For the three loading positions, rupture force can be predicted with the following equation in the range of the moisture content:

For Horizontal loading:

$$
\begin{aligned}
F_{R}=-3.3793 M^{2} & +111.76 M \\
& -778.03\left(R^{2}=0.9995\right)
\end{aligned}
$$

For vertical loading:

$$
F_{R}=-3.8754 M^{2}+126.44 M-870.09\left(R^{2}=0.9999\right)
$$

For edge-wise loading:

$$
F_{R}=-0.7309 M^{2}+30.741 M-233.5\left(R^{2}=0.9215\right)
$$

\subsubsection{Seed Hardness}

The hardness of the seed gives an idea of how much force it can stand or its firmness. It varies significantly with moisture and position as shown in figure 5 . It ranges from $6.97 \pm 0.16$ to $6.92 \pm 0.20 \mathrm{~N} / \mathrm{mm}$ for horizontal loading, $6.92 \pm 0.10$ to $6.67 \pm 0.09 \mathrm{~N} / \mathrm{mm}$ for edge-wise loading position and $6.99 \pm 0.10$ to $6.93 \pm 0.18 \mathrm{~N} / \mathrm{mm}$ for vertical loading respectively in the moisture content range of 10.6 to $18.4 \% \mathrm{wb}$ for all samples.

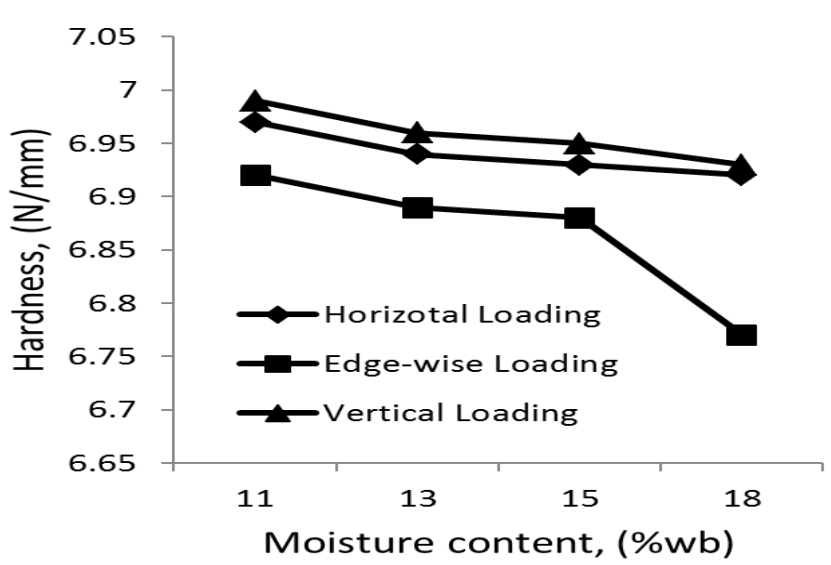

Figure 5: Hardness against moisture content

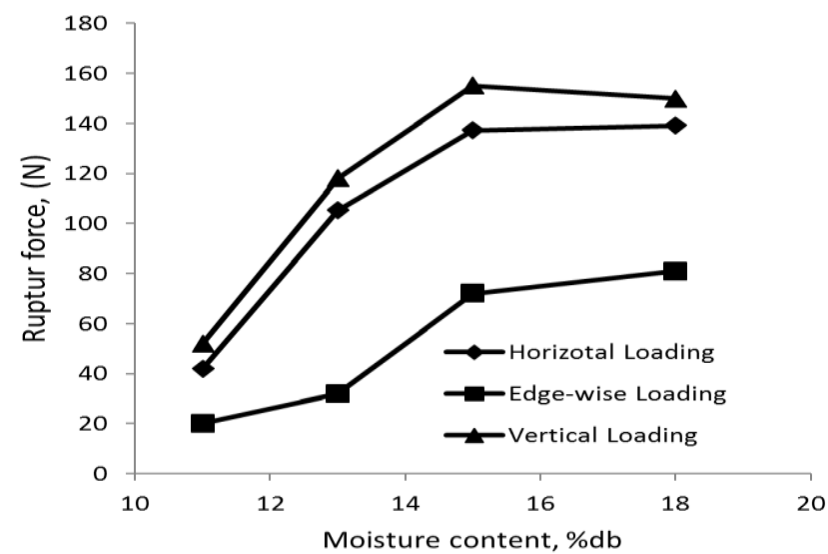

Figure 4: Rupture force against moisture content 


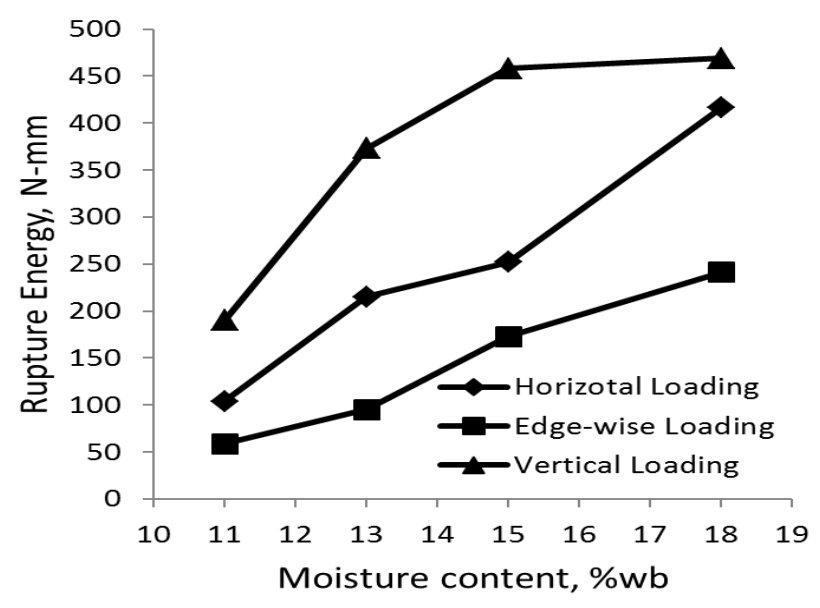

Figure 6: Rupture energy against moisture content

The empirical relationships between hardness and moisture content for the three loading positions are given in equations (13) to (15). For the three loading positions, hardness can be predicted with the following equation in the range of the moisture content:

For vertical position

$$
H=-0.019 M+7.01 \quad\left(R^{2}=0.9627\right)
$$

For horizontal position:

$$
H=-0.016 M+6.98\left(R^{2}=0.9143\right)
$$

Edge-wise loading:

$$
H=-0.046 M+6.98\left(R^{2}=0.8202\right)
$$

\subsubsection{Rupture Energy}

In the range of moisture content from $10.6 \%$ to $18.4 \%$ $\mathrm{wb}$, the rupture energy varied from $10 \mathrm{Nmm}$ to $416.33 \mathrm{Nmm}$ on horizontal loading, $59.96 \pm 21.6$ to $241.82 \pm 41.8 \mathrm{Nmmon}$ edge-loading and 190.125 to $419.171 \mathrm{Nmm}$ on vertical loading respectively. The plot of rupture energies of the seeds against moisture content at different loading positions are presented on figure 6.The parameter varied significantly with moisture content and loading positions.

The empirical relationship between rupture energy and moisture content are given in regression equations (16) to (18). For the three loading positions, rupture energy can be predicted with these following equations with a good degree of confidence in the range of the moisture content:

For horizontal loading:

$R_{E}=0.8572 M^{2}+17.729 M-185.69\left(R^{2}=0.9763\right)$

For vertical loading:

$$
R_{E}=42.7 M-361.74\left(R^{2}=0.9744\right)
$$

For edge wise loading:

$$
R_{E}=27.03 M-243.15\left(R^{2}=0.9840\right)
$$

\subsubsection{Toughness of the Seeds}

The toughness of the seeds as shown in Figure 7 shows a trend that suggests significant effect of moisture content on the parameter. It has an inverse relationship with moisture content in the range tested. In the range of moisture content of 10.6 to $18.4 \% \mathrm{wb}$ this material

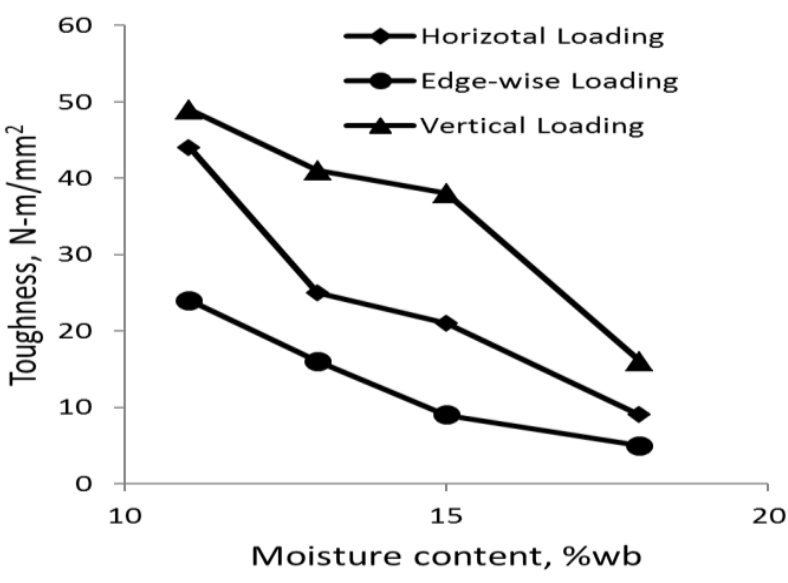

Figure 7: Toughness against moisture content

property varies from $43.75 \mathrm{~N}-\mathrm{m} / \mathrm{mm}$ to $8.865 \mathrm{~N}-\mathrm{m} / \mathrm{mm}$ for horizontal loading, from $23.563 \mathrm{~N}-\mathrm{m} / \mathrm{mm}$ to $5.370 \mathrm{~N}$ $\mathrm{mm} / \mathrm{mm}$ for edge-wise loading and from $44.667 \pm 11.87$ to $16.349 \pm 6.91 \mathrm{~N}-\mathrm{m} / \mathrm{mm}$ for vertical loading respectively. The effect of moisture on toughness can easily be seen on the graph.

The empirical relationship between toughness (T) and moisture content are given in Equations (22) to (24). For the three loading positions, toughness can be predicted with the following equation in the range of the moisture content:

Horizontal loading:

$$
T=-4.66 M+91.01 \quad\left(R^{2}=0.9194\right)
$$

Vertical loading

$$
T=-4.56 M-100.99 \quad\left(R^{2}=0.9305\right)
$$

Edge-wise loading:

$$
T=-2.71 M-52.12 \quad\left(R^{2}=0.9402\right)
$$

\subsubsection{Elastic Modulus}

The modulus of elasticity of the seeds showed some variations with moisture content. It dropped from 35.657 to $28.133 \mathrm{~N} / \mathrm{mm}^{2}$ for horizontal loading, from 51.443 to 14.59 for edge-wise loading and 38.087 to $41.04 \mathrm{~N} / \mathrm{mm}^{2}$ when loaded vertically, in the range of moisture content of 10.6 to $18.4 \% \mathrm{wb}$ respectively. The plot of elastic modulus against moisture content is presented in Figure 8.

The empirical relationship between toughness and moisture content are given in equations (25) to (27). For the three loading positions, toughness can be predicted with the following equation in the range of the moisture content used in the study.

Vertical loading:

Horizontal loading:

$$
E=-0.846 M+47.44 \quad\left(R^{2}=0.872\right)
$$

$$
E=-0.981 M+47.11 \quad\left(R^{2}=0.8896\right)
$$

For Edge-wise loading:

$$
E=-2.127 M+52.815\left(R^{2}=0.9713\right)
$$




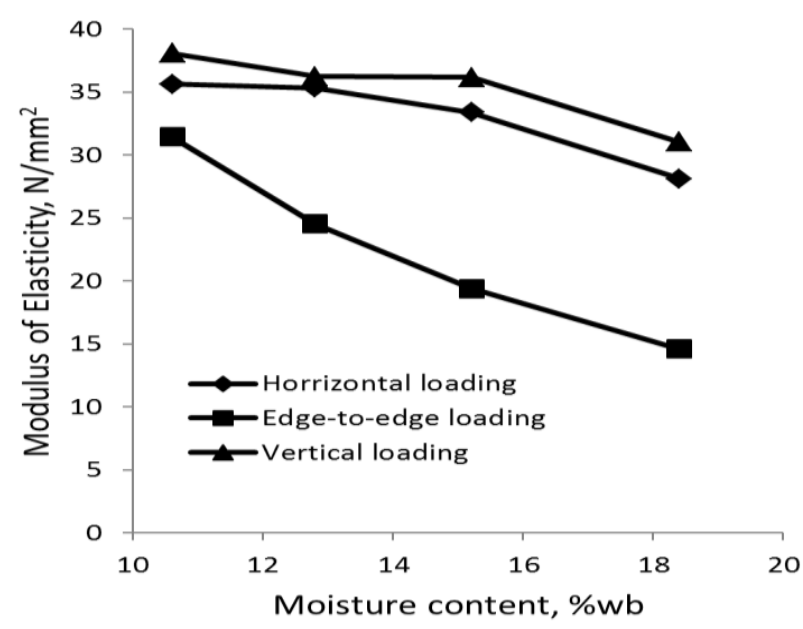

Figure 8: Elastic modulus of the Afzelia Africana seed against moisture content

\section{CONCLUSIONS}

Some physical and mechanical properties of the seeds of Afzelia Africana were experimentally determined at room temperature of $31^{\circ} \mathrm{C}$ in the reconstituted moisture content range of $10.6 \% \mathrm{wb}$ to $18.4 \% \mathrm{wb}$. The physical characteristics such as major, minor and intermediate diameter were directly measured by vernier calipers. Others, such as arithmetic mean diameter, geometric mean diameters, sphericity, bulk density, porosity and surface area were calculated, using the primary dimensions of weight and linear dimensions obtained from the measurements.

The physical characteristics generally did not show significant variation with moisture content in the range of moisture content studied and other experimental conditions. This can be attributed to the hard seed coat which may restrain the cotyledon from expansion or shrinkage under wetting and dehydration.

Among the mechanical properties studied, there was significant difference in the means of the three loading conditions. Rupture force, rupture energy and toughness varied significantly with moisture content as well as loading position in the range of moisture content tested and the prevailing laboratory conditions.

The rupture force was highest for vertical loading with $155.68 \mathrm{~N}$, followed by horizontal loading with $139 \mathrm{~N}$ and least for edge-wise loading with $81 \mathrm{~N}$. It can therefore be deduced from the results that in shelling operation, the seed loaded on its edges will reduce the energy requirement.

The data generated in this study as envisioned are useful in the estimation of the energy needed for decorticating the seed and the loading condition that will demand the least energy for the operation. The thermo-physical properties are also needed in other process design and analysis involving seeds of Afezelia Africana and therefore should be investigated in future studies.

\section{REFERENCES}

[1] Brenan, J. P. M.. Flora of tropical east Africa, Leguminosae. Crown agents for oversea governments and administrations, London, United Kingdom. 230pp. 1967

[2] Orwa C, Mutua A, Kindt R, Jamnadass R. and Simons A. Agroforestry Database: A Tree Reference and Selection Guide Version (4). 2011

[3] Hawthorne W. and Jongkind C., Woody Plants of Western African Forest: a Guide to the Forest Trees, Shrubs and Lianas from Senegal to Ghana. Kew Publishing, Royal Botanic Gardens, kew, United Kingdom. 1023 pp. 2006.

[4] Ejikeme P. M., Obasi, L. N. and Egbuonu, A. C. Physico-chemical and toxicological studies on Afzelia Africana seed and oil. African Journal of Biotechnology. 9 (13): 1959-1963, 2009.

[5] Aremu A. K. and Fadele, O. K. Study of some properties of Doum palm fruit (Hyphaenethebaica Mart.) in relation to moisture content. African Journal of Agricultural Research 6(15): 3597-3602. 2011.

[6] ASAE Agricultural Engineer Year Book of Standards. American Society of Agric Engineers (ASAE) St. Josephs, Michigan, U.S.A. 1983.

[7] Mohsenin N. N. Physical Properties of Plant and Animal Materials. New York: Gordon and Breach publishers. 1980.

[8] 8 Olajide, J. D., and Ade-Omowaye B. I. O. Some physical properties of locust bean seed. Journal of Agricultural Engineering Research, 74 (2): 213-215. 1999.

[9] Baryeh E. A. Physical properties of bambara groundnuts. J Food Eng. 47: 321-326. 2001.

[10] Mohsenin N. N.. Physical Properties of Plant and Animal Materials. vol. 1, Gordon and Breich Series publication, London, pp. 825-837. 1986.

[11] Gholami, R., A. N. Lorestani, T. F. Jalilian.. Determination of physical and mechanical properties of Zucchini (summer squash). Agric Eng Int: CIGR Journal, 14 (1). 2012.

[12] Khodabakhshian B. and Emadi B.. Determination of the modulus of elasticity in agricultural seeds on the basis of elasticity theory. Journal of scientific research 7(3): 367-373. 2011.

[13] Nwuba E. I. U. Selected Physical and Mechanical Properties of Cowpea as related to Mechanical threshing of the entire Plant Shoot. Ph.D. Thesis, Ahmadu Bello University Zaria Nigeria.

[14] Nwuba E. I. U., Arinze E. A., Braide F. G. Development of whole crop cowpea thresher as affected by grain and stalk properties. Journal of Agricultural Engineering and Technology, Vol. 2 pp 67-79. 1994. 